\title{
Professional versus family management in Brazilian fashion retail companies: exploring value-investors' perceptions
}

\author{
CLARICE SECCHES Kogut \\ INSTITUTO COPPEAD DE ADMINISTRAÇÃO- UFRJ, RIO DE JANEIRO - RJ, BRAZIL \\ DENISE FLECK \\ INSTITUTO COPPEAD DE ADMINISTRAÇÃO- UFRJ, RIO DE JANEIRO - RJ, BRAZIL
}

\begin{abstract}
Regarding the debate on which sort of management - professional or family administration - would more effectively run businesses, this paper discusses the advantages and shortcomings of family and professional management from a theoretical and a practitioner's viewpoint. The study aims at contributing to our understanding about the superiority that either type of management might have delivering longterm performance and value creation to shareholders. Six investors from top value investment funds were interviewed regarding the management of seven fashion retail Brazilian companies. Data analysis revealed that investors do not prefer either type of management family or professional - when they make investments. Instead, they do look for specific characteristics and patterns of behavior in a CEO, which resemble Selznick's (1957) definition of an institutional leader. Finally, the paper suggests a new path of research for scholars (relating old institutionalism and professionalism) and practical guidelines for each type of management (family or professional), offering, therefore, an academic as well as a practical contribution.
\end{abstract}

Keywords: Family firms. Family business. Professional management. Professionalism. Value-investors.

Gerenciamento profissional versus familiar em empresas brasileiras de varejo de moda: explorando as percepções dos analistas de investimento em valor

\begin{abstract}
Resumo
Contrastando a visão acadêmica com a de investidores em valor, este artigo discute os prós e contras de gestão familiar e gestão profissional em empresas brasileiras, visando contribuir para a discussão sobre que tipo de gestão seria preferível em termos de desempenho de longo prazo e de criação de valor para os acionistas. Seis investidores de fundos de investimento em valor foram entrevistados pessoalmente a respeito do gerenciamento de empresas de varejo de moda. Conclui-se que investidores não têm preferência por um tipo de gestão na hora de investir, mas sim por características e padrões de comportamento específicos em um CEO, similares em muitos aspectos aos descritos por Selznick (1957) como os de um líder institucional. Finalmente, novos caminhos de pesquisa são indicados para acadêmicos (relacionando o velho institucionalismo com profissionalização) e orientações práticas são dadas para cada tipo de gestão (familiar ou profissional), tendo, portanto, uma contribuição tanto acadêmica quanto prática.
\end{abstract}

Palavras-chave: Empresas familiares. Gerenciamento familiar. Gerenciamento profissional. Profissionalização. Investimento em valor.

Gestión profesional versus gestión familiar en empresas minoristas de moda brasileña: explorando las percepciones de los analistas de inversiones en valores

\section{Resumen}

Al contrastar la visión académica con la de los inversores en valores, este artículo discute los pros y los contras de la gestión familiar y la gestión profesional en las empresas brasileñas, con el objetivo de contribuir al debate sobre qué tipo de gestión sería preferible en términos de rendimiento a largo plazo y creación de valor para los accionistas. Se entrevistó personalmente a seis inversores en fondos de inversión en valores con respecto a la gestión de empresas minoristas de moda. Se concluye que los inversores no tienen preferencia por un tipo de gestión a la hora de invertir, sino por las características y patrones de comportamiento específicos de un CEO, similares en muchos aspectos a los descritos por Selznick (1957) como los de un líder institucional. Por último, se indican nuevos caminos de investigación a los académicos (relacionando el antiguo institucionalismo con la profesionalización) y se dan orientaciones prácticas para cada tipo de gestión (familiar o profesional), aportando, por lo tanto, importantes contribuciones tanto académicas como prácticas.

Palabras clave: Empresas familiares. Gestión familiar. Gestión profesional. Profesionalización. Inversores en valores.

Article submitted on October 13, 2015 and accepted for publication on July 7, 2017.

The authors thank the supportive comments and suggestions of three anonymous reviewers and acknowledge the financial support of CNPq

[Original version]

DOI: http://dx.doi.org/10.1590/1679-395156974 


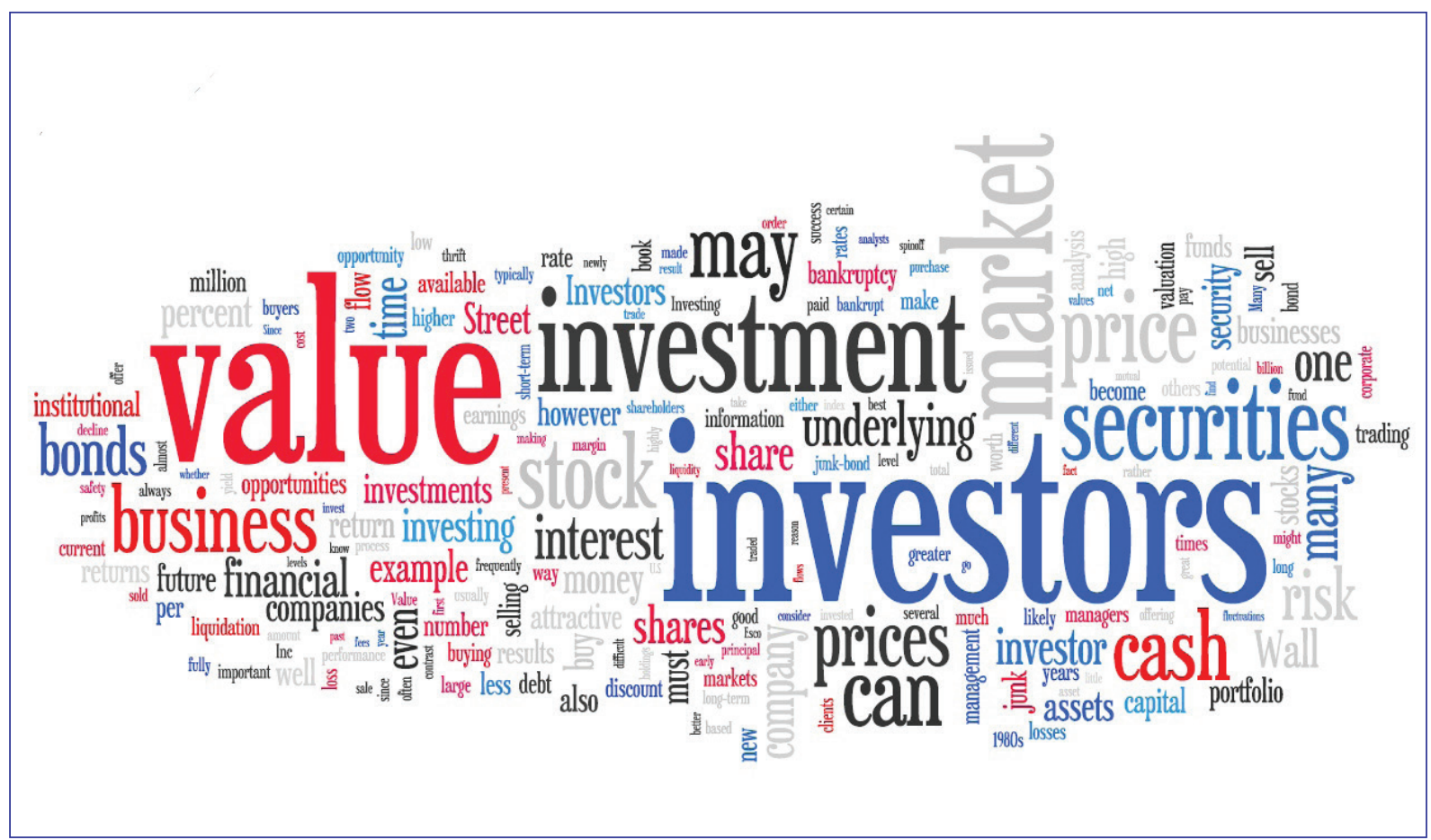

\section{INTRODUCTION}

Family businesses are central to the world economy. In fact, they comprise over two thirds of all businesses in the industrialized economies and about one third of the companies listed in the S\&P500 ${ }^{1}$ index (MILLER and LE BRETON-MILLER, 2006; JONES, 2005; ALLIO, 2004; DYER, 1989). In Latin America, 70 to 80 percent of businesses are family-owned, reaching even higher proportions in Mexico and Brazil (QUEIROZ, 2007; TREVINYO-RODRIGUEZ, 2009). However, as businesses mature and succession problems emerge, several family-owned firms consider adopting the professional management alternative. This leads one to wonder which, if any, type of management - family of professional - would more effectively deliver long-term performance and value creation to shareholders.

Rather than trivial, this is a strategic issue. While some scholars would argue in favor of family management as a way to enable the preservation of founders' core values and alignment of interests (GAMA and RODRIGUES, 2013; MILLER and LE BRETONMILLER, 2006; ALLIO, 2004), others would favor professional management's rationality, tools and techniques (SCIASCIA and MAZZOLA, 2008; GALLO, TAPIES and CAPPUYNS, 2004).

While both the academic and the practitioners' fields have discussed this topic, how investors and financial analysts perceive the issue is rather obscure. Financial aspects in the literature that contrasts family and professional management (GAMA and RODRIGUES, 2013; SCIASCIA and MAZZOLA, 2008; MILLER and LE BRETON-MILLER, 2006; ALLIO, 2004; GALLO, TAPIES and CAPPUYNS, 2004) usually focus on financial ratios comparisons, and are inconclusive with respect to which management

Image source: Futureblind. Available at: https://futureblind.com/2008/09/13/value-investing-word-clouds/. Accessed on July 20, 2017.

${ }^{1}$ The S\&P 500 is a stock index, created by Standard \& Poors in 1957, although it has been extrapolated backwards for performance comparison purposes This index provides a broad snapshot of the overall U.S. equity market; with over $70 \%$ of all U.S. equity being tracked by the S\&P 500 . The index selects its companies based upon their market size, liquidity, and sector. Source: <http://www.investorwords.com/4378/SP_500.html\#ixzz4gDvxd31Z>. Accessed on Sept. 30, 2015. 
mode would be more effective. Moreover, whether a company's type of management would play a relevant role in investors and financial analysts investment decisions remains an open question.

This paper explores the perceptions of value investors on the family versus professional management issue regarding fashion shoes and apparel retail firms in Brazil. This specific segment of the financial sector comprises investors who, in addition to scrutinizing financial figures, actually devote time and effort to the analysis of companies' management. Their in-depth analyses on management are long-term oriented, including both quantitative and qualitative aspects. The fashion shoes and apparel retail sector constitutes an interesting site for investigation for organizational and economic reasons. For one, there are as roughly many family-managed as professionally managed companies in the sector. In addition, the fashion apparel industry currently experiences consolidation and professionalization change (VENTURA, 2010). Finally, the economic relevance of this sector is indisputable: according to PWC (2014), the Brazil is the fifth largest consumer market in the world, with total retailing economic activity in close to $25 \%$ of Brazilian's GDP (IDV, 2014), and fashion shoes and apparel responding for roughly $12 \%$ of it - or $3 \%$ of total GDP (ABVTEX, 2016).

In view of the relevance of and the inconclusive findings about the subject matter, this study aims at shedding some light on this ongoing debate, investigating an ill-explored segment of practitioners, the value investors, from a qualitative perspective.

In what follows, the paper first introduces the theoretical background, then describes the research method, discusses the results of the analysis, and finally advances some concluding remarks.

\section{THEORETICAL BACKGROUND}

Despite the worldwide prevalence of family-owned firms - over two thirds of all businesses in the industrialized economies and about one third of the S\&P500 (MILLER and LE BRETON-MILLER, 2006; JONES, 2005; ALLIO, 2004; DYER, 1989), and 70 to $80 \%$ of all businesses in Latin America (QUEIROZ, 2007; TREVINYO-RODRIGUEZ, 2009) - their study remains marginal in management research. Contributing an anthropological explanation for such imbalance, Jones (2005) maintains that family firms would not be associated with science and objectivity, but with a private, domestic domain - a view Queiroz (2007) endorses.

Research in Family Business is a relatively new field of study, still very dispersed and fragmented. Regarding the most researched topics, Chua, Chrisman and Sharma (2003) ranked, in order of importance, succession, professional advice, types of family businesses, board of directors, transition towards professional management, life cycle stages of family businesses and others. Casillas and Acedo's field review (2007) advanced similar findings. In their view, succession is family firms' main challenge, while planning, professionalism, division of personal roles and use of external counselors and advisors are tools that may help overcome this and other challenges such as governance and strategic management, among others. Another field review which also establishes succession as the most researched topic, followed by governance and strategic management, states that "More effort is needed to address the complexity of family companies and to understand how they are similar and different from other types of organizations" (SCHULZE, LUBATKIN and DINO, 2003a, p. 41 apud BENAVIDES-VELASCO, QUINTANA-GARCIA and GUZMAN-PARRA, 2013). Interpersonal family dynamics and conflict are another important issues concerning family firms, as family members are "locked" in a firm, making conflicts more persistent and interests more difficult to align. Other relevant topics include business performance and growth, and financial management, which correspond to $6.4 \%$ and $7.2 \%$ of the total of articles analyzed by the authors in the period 1961-2008 (BENAVIDES-VELASCO, QUINTANA-GARCIA and GUZMAN-PARRA, 2013).

Inconclusive findings are a typical trait of research on family firms. This includes the very definition of what a "family firm" is (CASILLAS and ACEDO, 2007; BENAVIDES-VELASCO, QUINTANA-GARCIA and GUZMAN-PARRA, 2013; RODRIGUES and ANDRE, 2013). This paper views family firms as those in which one or more families have direct ownership control and governance, and participate in the top management of the company (CHUA, CHRISMAN and SHARMA, 2003; RODRIGUES and ANDRE, 2013). Maintaining generational continuity as a strategic goal of the firm is a feature, which may help distinguish family from nonfamily firms. 


\section{On the origins and development of professional management}

According to Chandler's (1977) account of the American business development, the Modern Business Enterprise (MBE) emerged in the 19th century. These multiunit business organizations were managed by salaried managers and could take three forms: entrepreneurial (controlled by families), financial (controlled by bankers and investors) or managerial (controlled by professional managers). Chandler's historical account maintains that over time, organizations tended to take the managerial form, as hired managers provided the MBE with a continuing existence propensity for two reasons: they could be replaced and they sought for a lifetime career in their firms. Because families could not provide as many managers as firm growth required, family-owned firms would tend to evolve into the MBE form and become corporations. Chandler (1977) viewed the corporation as "the most powerful institution in the American economy" (p. 1) and the reason of the country's success. The notion of professional managers has emerged because of the increasing complexity in running ever-bigger organizations. Not only owner families were not able to provide enough family members to run the growing firms, but also, in many cases, those members lacked the required managerial and intellectual capabilities. Those growing firms would then seek an outside, supposedly more objective, and professional managers often trained at the business schools, which emerged by that time (JONES, 2005; MORRIS, WILLIAMS and NEL, 1996).

While true in the past, Fleck (2003) raises the question as to whether the pursuit of a lifetime career is still as strong as it may have been throughout the historical period Chandler describes. In fact, Fleck (2003) suggests that management mobility across firms could actually hinder the growth of the firm, being therefore detrimental to shareholders. Miller and Le BretonMiller (2006) also provide evidence that is at variance with Chandler's lifetime career argument in recent times: according to the authors, "the average CEO tenure at family-run businesses is said to range between 15 and 25 years, while that of a typical public, non-FCB (family controlled business) leader has reduced to three to four years" (p. 78).

The increased complexity of businesses in the second half of the $20^{\text {th }}$ century has stimulated research on the implications for growing firms of the growth process, as well as on the role management might play in fostering their long-term continued existence. The growth process has inspired the development of life cycle or stage models theories. A case in point is Greiner's evolution and revolution theory (GREINER, 1972). This perspective claims that management styles and strategies that fit one specific stage of organizational development are no longer suitable to the following stage of evolution. A revolutionary period would then ensue and the growth of the firm depends on how well the managerial styles and strategies change to fit the requirements of the upcoming stage. Other examples include Peçanha and Oliveira (2015), Trevinyo-Rodriguez (2009), Charan and Hofer (1984) and Whetten (1987). Likewise, Berenbeim (1990) states that high growth rates are necessary for the founder to achieve freedom of action (attract talent and be less dependent on external financing). Yet, as the firm grows, so does the companies' need for a more sophisticated management.

Concerning the long-term continued existence of organizations, Selznick (1957) puts forward the notion of institutional leadership, which he views as a key contributing element to organizational longevity. According to him, institutional leaders combine three features: leadership (responsible and creative), character and critical experience, independently of being a family member or a professional manager. He defines responsible leadership as "a blend of commitment, understanding and determination" (p. 143), leading to the avoidance of opportunism (short-term, immediate advantages in detriment of the long run or possibly impacting organization's character) and of utopianism (avoiding hard choices). Creative leadership, on the other hand, refers to infusing purpose to an organization and doing its strategic and tactical planning. One way of exercising it, is through the creation of myths, which contributes to a unified sense of mission and helps build an institution. Summing it up, by being a responsible and creative leader, in addition to having strong character and critical experience, one infuses values in the organization, thus moving away from being a mere organizational manager to becoming a true institutional leader.

While one might expect that professional management would yield better financial results than family members likely would, research studies lack consensus regarding which type of management, family or professional, would generate better financial results. This is the subject matter next section addresses. Thereafter, two sections focus on two topics that affect organizational continued existence over the long-term, i.e. succession and corporate governance issues. 


\section{Firms and performance}

This paper views financial performance as "financial returns generated by the firm - typically measured by the returns on the assets or equity of the business - that are available to all public shareholders of the firm, family or otherwise, either via dividends or stock market returns" (MILLER and LE BRETON-MILLER, 2006, p.74). The literature so far lacks consensus on whether professional management yields superior financial performance than family management. Chart 1 illustrates the position of some representative studies on this matter, distinguishing those in favor of family managed superiority from those supporting professionally managed superiority.

\section{Chart 1}

\section{Representative studies' positions regarding the type of management generating better financial performance}

\begin{tabular}{|l|l|}
\hline \multicolumn{1}{|c|}{ Family Managed firms superiority } & \multicolumn{1}{c|}{ Professionally Managed firms superiority } \\
\hline $\begin{array}{l}\text { Gama and Rodrigues (2013) } \\
\text { Allio, M. K (2004) }\end{array}$ & $\begin{array}{l}\text { Sciascia and Mazzola (2008) } \\
\text { Giller and Le Breton-Miller (2006) Tapies and Cappuyns (2004) }\end{array}$ \\
\hline
\end{tabular}

Source: Elaborated by the authors.

Both agency theory and stewardship theory suggest that the greater one's ownership in the company, the greater one's commitment will likely be and the less likely it is that one will squander financial resources of the company (CHUA, CHRISMAN and SHARMA, 2003; JONES, 2005). On the other hand, conventional Druckerian management thinking assumes family members involved in management are more likely (and not less) to "free ride". This perspective, thus, favors a scientifically educated professional management over a family one (JONES, 2005).

According to Jones (2005), the belief on the superiority of professional management over family management would be part of a cultural schema based on market capitalism. In this sort of capitalism, the most powerful symbol is the public corporation, which business schools and consulting firms usually associate with professionally managed firms. As for family firms, Jones maintains that "despite their statistical significance, [they] would fall outside of this dominant cultural schema, and are, then, because they are founded on an anthropological principle of kinship and not (primarily) on the principle of the market, subversive" (p. 277). As a result, in a cultural construct based on a structured dualism, family firms (in opposition to professional) would be most commonly associated with emotion (over reason), humanities (over science), private (over public), soft (over hard), subjective (over objective).

Yet, such simplifications do not fit family firms, since they attend to multiple logics in multiple spaces: "spatially situated in both the aggressive, male universe of competitive capitalism, and in the domestic, anthropological space of kinship and family social organizations" (JONES, 2005, p. 282). Likewise, Queiroz (2007) believes family firms have two conflicting forces: an economic one pushing for profits (firm's goal) and a family one pushing for members' well-being (family's goal), with the expression "family firm" being therefore a paradox.

Allio (2004) associates the superiority of family firms in delivering financial performance with several aspects, such as their managers/owners higher levels of loyalty to the firm, focus, speed of execution, deeper pockets for growth and commitment to implementation (follow-through). On the other hand, he also identifies some flipside elements. For one, too much loyalty to the family can lead to nepotism, irrational decision-making and unfair compensation to family members. In addition, too much speed can lead to impulsiveness in decision-making, and too much focus can lead to myopia. Moreover, too much focus on growth can lead to emotional investments rather than rational ones and too much focus on follow-through can lead to compulsive attention to daily tactical details instead of strategy. 
So, rather than being just a matter of cultural bias against family managed firms, the list of potential problems that impair financial performance in family managed firms includes several items. One such issue refers to nepotism and lack of professional competence (DYER, 1989; SCIASCIA and MAZZOLA, 2008; MILLER and LE BRETON-MILLER, 2006). Another one concerns conflicts regarding divergent/ competing goals of shareholders/family members (SCIASCIA and MAZZOLA, 2008; TREVINYORODRIGUEZ, 2009; MILLER and LE BRETON-MILLER, 2006). Two other ones have to do with the use of business resources for personal benefit and in detriment of minority shareholders (MILLER and LE BRETON-MILLER, 2006), and lack of transparency and access to information (BENAVIDES-VELASCO, QUINTANA-GARCIA and GUZMAN-PARRA, 2013). Finally, the pursuit of nonfinancial or personal goals by family members (GALLO, TAPIES and CAPPUYNS, 2008; SCIASCIA and MAZZOLA, 2008) is also a tricky issue in family managed organizations.

On top of that, Miller and Le Breton-Miller (2006) stress that family firms lack adequate "access to capital due to ever-increasing needs of a growing family (CHANDLER, 1990) and because of skepticism by financial markets" (p. 73). According to Sciascia and Mazzola (2008), "in order to improve performance and firm value, companies operating on the capital markets must be sensitive to both shareholders and investors who need greater transparency and disclosure from family firms" (p. 52).

Dyer (1989) has highlighetd a few differences between family and professional managers. The latter tend to make more logics- and reason-grounded decisions than intuition-based ones. In addition, professional managers are more likely prone to developing impersonal interactions with others, while the founder and family members, who have a personal history with the company and employees, tend to embrace a more personal style. Family members' training is usually more informal, individual and technical (not managerial). In contrast, professional managers' training is usually collective, taking place in MBA classrooms, which emphasize the development of formal, generic standardized skills.

According to Dolz, Iborra and Safón (2015), the fact that family firms usually have more than one generation at decision-making positions, provides them with higher diversity of age and experience, as well as an enhanced perception of environmental change and ability to respond to it.

In addition, according to Hall and Nodqvist (2008), "professional family business management rests on two competencies, formal and cultural, of which only the former is explicitly recognized in current family business literature". For these authors, management by family members should be seen as professional management as well, and those who fail to view it this way share a simplified and outdated perspective of professional management. The cultural understanding of the company (cultural competence) seems to be a criterion used to select new CEOs in succession processes. Muzzio (2013) corroborates this view, instigating professional managers, especially those early in the professionalization process of the firm, to develop a cultural competence and keep the founders' legacy. In their study, Gama and Rodrigues (2013) have found that while family firms may have better accounting performance than professional ones, this does not translate into higher valuation levels and might not accrue to minority shareholders if the right governance mechanisms are not in place.

As a final remark, many scholars do not differentiate between family involvement in management (FIM) and family involvement in ownership (FIO). Important exceptions include Sciascia and Mazzola (2008) and Miller and Le Breton-Miller (2006). Both studies identify different effects FIM and FIO have on performance. FIM is more likely to produce superior financial performance than FIO, although several conditioning factors may apply.

\section{Succession}

Family business succession has to do with "the passing of the leadership baton from the founder-owner to a successor who will either be a family member or a non-family member, that is a 'professional manager' " (BECKHARD and BURKE, 1983, p. 3 apud HANDLER, 1994). A more comprehensive view of succession includes the passing of the leadership baton from one generation to the next one. Most scholars agree that succession, either to a family member or to an outside professional manager, can be quite traumatic. "Family firms represent relatively stable systems so long as the founding entrepreneur is in place" (MORRIS, WILLIANS and NEL, 1996, p. 69). Still, succession planning is not often done (HANDLER, 1994) even though it has yielded positive results when applied (MORRIS, WILLIANS and NEL, 1996). After the initial difficulties of setting up the business, "the most likely causes of business failures are the problems encountered in the transition from a one-person, entrepreneurial style of management to a functionally organized, professional management team" (CHARAN and HOFER, 1984). 
Statistics show that only a third of family firms survive the transition to the second generation and only 12 percent make it to the third (ALLIO, 2004). In analyzing succession processes Teston and Filippim (2016) list as determinant aspects of preparation the founder's influence, multigenerational socialization, demographical aspects and learning. Muzzio (2013) raises the importance of the professional manager keeping the founder's legacy for the success of the succession process and of the business as a whole.

\section{Conflicts and corporate governance}

According to Cyert and March (1963), organizations constitute a coalition of individuals united with a common purpose. In their view, organizations do not have objectives or goals; individuals do. Whenever organizational stakeholders diverge with respect to goals, organizational instability and conflict result.

Two opposing perspectives contribute insights into the corporate governance of family firms. The first, agency theory, advances some factors that lead management to seek its own interest to the detriment of the best interest of shareholders. Such factors include asymmetry of information (managers knowing more than owners) and a potential conflict of interest between managers (agents) and shareholders (principal). Several mechanisms including compensation packages and overseeing boards exist to align and monitor managers' and shareholders' financial interests.

The principal-agent problem is typical of professionally managed firms, whereas it is less relevant in family managed firms unless there are conflicting interests among shareholders. Gama and Rodrigues (2003) and Miller and Le Breton-Miller (2006) have raised another important agency problem concerning family firms, a "principal-principal" problem. The concentration of ownership and management of a publicly-held corporation in the hands of a family creates room for a potential conflict between controlling shareholders and minority shareholders, with the former possibly making decisions that are beneficial to them but detrimental to the last. Hence, the need for governance procedures and external monitors arises.

The second perspective, stewardship theory, stresses the emotional and financial attachment to the business that some top managers experience. Such feelings may refrain them from grounding their actions exclusively on self-serving economic principles, leading them also "to act with altruism, for the benefit of the organization and its stakeholders" (MILLER and LE BRETON-MILLER, 2006, p. 74). Stewardship is usually present in top managers that are either family members or individuals emotionally linked to the family (MILLER and LE BRETON-MILLER, 2006).

\section{Research Objectives and Method}

The study reported in this paper sought to capture financial investors' perceptions on the family versus professional management issue regarding fashion shoes and apparel retail firms in the Brazilian economy. To carry out an exploratory investigation on this matter, the study has performed a qualitative analysis of the collected data, which comprises interviews with representatives of major Brazilian investment houses, and "letters to investors" these houses issue in order to disclose to their clients their performance, investment policies and beliefs.

\section{Delimitation of the study}

While the spectrum of financial investors ranges from pure speculators to true business investors, this research has focused on value investors. In addition to scrutinizing financial figures, these investors actually devote time and effort to analyze companies' management. The investment firms that make up the value investment community share a set of principles. These are in line with the theory of Graham (1949), Graham and Dodd (1951) and with Warren Buffet's practice. Buffet, often viewed as the most successful investor of all times, was a former student and employee of Graham at his investment firm.

According to Hagstrom (2005), the main concepts Warren Buffet has adopted from Graham's ideas include: 
i) margin of safety (buying at a market price lower than the underlying business' value);

ii) long-term horizon of investment;

iii) buying businesses, not stocks (acting as business owners);

iv) independent judgment (decisions based on sound and logic conclusions, not on peer movements); and

v) being aware of market speculative characteristics (people's greed and fear cause the stock prices to reach values that go far below or beyond a company's intrinsic value. In such circumstances, there is room for investment, which can benefit those who rely on logical reasoning and refrain from emotional reactions).

Buffet, however, has added a few other concepts into his investment policies derived from his professional and academic experiences (HAGSTROM, 2005). These include the importance of (i) management; (ii) the business itself; and (iii) looking to other sources of information besides balance sheets and annual reports, such as interviews with clients, suppliers, employees. Namely, Buffet's investment analysis combines qualitative and quantitative scrutiny. Regarding the focus of this paper - the importance of management - Buffet emphasizes honest and competent managers, who he must admire and trust (HAGSTROM, 2005). In analyzing a business investment, Buffet investigates whether management is rational in its decisions; whether management is candid to shareholders (admitting mistakes and having a full disclosure posture); and whether management resists the institutional "imperative", which may force management into blindly following industry peers.

\section{Sample selection}

In consonance with the purpose of investigating financial investors' perceptions on the family versus professional management issue regarding fashion shoe and apparel retail firms in the Brazilian economy, the study has selected a theoretical and contextually relevant sample (EISENHARDT and GRAEBNER, 2007), which has enabled in-depth analysis.

Six individuals were personally interviewed by one of the authors between April $20^{\text {th }}, 2015$ and April $30^{\text {th }}, 2015$. Being in charge of the investment decisions of three top investment firms in Brazil, these investors share a strong belief in value investment concepts. The investment firms selection included two criteria. First, their financial relevance - together they manage over $\mathrm{R} \$ 12$ billion, accounting for over $7 \%$ of the Brazilian total investment fund's net worth. Second, their intellectual relevance - all three firms hold a strong reputation in the market, they are perceived as opinion-makers or influencers, and their performance had beaten the IBOVESPA benchmark over the previous 12, 36 and 60 months (AMBIMA, 2015).

Three characteristics of the Brazilian fashion shoe and apparel retail segment make it an adequate research site. First, there are instances of family and professional management among publicly traded companies. Second, the investigated issue is relevant and timely, in view of the sector's current stage of development. In fact, the ongoing process of consolidation and professionalization in this segment has attracted new investors from the capital markets and has compelled firms to make use of more complex organizational structures (VENTURA, 2010). Finally, the fashion retail sector is economically relevant, with revenues of over US\$56 billion in 2016, about 3\% of the country's GDP (ABVTEX, 2016).

The interviews prompted respondents to assess and comment on the management of following companies: Arezzo, Renner, Riachuelo, Marisa, Hering, Restoque and Inbrands. None of the interviewees has any personal relationship with any individual in these companies.

\section{Data collection and preparation}

All interviews took place at the investors' offices. Open questions sought to capture information on two main issues: the interviewees' investment processes and the interviewee's assessment of the seven selected companies' management. The questions covered several issues, such as the interviewee's view on the management of the seven companies, and the interviewee's own preferences with respect to management style, particularly concerning family versus professional management, among other topics. Following the open questions, they all gave their evaluation of each company's top management. Some of them did rank the firms in order of preference. 
As a data collection method, interviewing is not without shortcomings. Not only there is a very personal aspect in the collected data, but also distinguishing facts from individual opinions can be challenging (MANN, 1979). In view of the exploratory nature and purposes of this study, however, this method is suitable, if one introduces some additional procedures. In fact, in order to neutralize inherent deficiencies of the interviewing method and increase validity, data collection included two triangulation procedures (EISENHARDT, 1989): interviewing more than one person from each investment house and scrutinizing the most recent "letter to investors" each investment house issued.

\section{Data analysis}

Each interview was fully transcribed and analyzed. Analytical procedures comprised identifying statements related to subject matters addressed in the theoretical background - family and professional management, corporate governance and performance - as well as coding Selznick's (1957) institutional leader characteristics: leadership (L), character (C) and critical experience (CE). In addition, for triangulation purposes, data analysis compared and contrasted interview contents among same house investors, as well as against the "letters to investors". Finally, data analysis compared and contrasted interview contents among competing investment houses. Next section reports and discusses research results and analysis.

\section{RESULTS AND ANALYSIS}

Chart 2 summarizes some key characteristics of the investigated retail companies as well as how investors perceive the quality of their management.

\section{Chart 2}

\section{Main characteristics of analyzed companies}

\begin{tabular}{|c|c|c|c|c|c|c|c|}
\hline Companies & Arezzo & Renner & Riachuelo & Marisa & Hering & Restoque & Inbrands \\
\hline \multicolumn{8}{|l|}{ Publicly } \\
\hline traded & Yes & Yes & Yes & Yes & Yes & Yes & In process \\
\hline Family ownership & Yes & No & Yes & Yes & Yes & No & No \\
\hline Management type & Family & Prof. & Family & Family & Family & Prof. & Prof. \\
\hline $\begin{array}{l}\text { Founder on daily } \\
\text { decisions }\end{array}$ & No & No & Yes & Yes & Yes & No & No \\
\hline $\begin{array}{l}\text { Evaluation of } \\
\text { Management }\end{array}$ & Excellent & Excellent & Weak & Weak & Weak & "crazy"(a) & Weak \\
\hline
\end{tabular}

(a)Term used by investors, meaning irrational and unpredictable

Source: Elaborated by the authors.

\section{Family versus professional management: a CEO's desirable traits}

Chart 2 data do not suggest any apparent association between the type of ownership, type of management and investors' evaluation. This reflects the fact that all interviewees declared to have no clear preference for either type of management familiar or professional. Instead, what they valued had to do with having in charge an individual qualified for the task.

For several reasons, this finding seems unexpected. For one, mainstream historical management thinking views professional management as a natural evolution for family firms. In addition, because financial investors are minority shareholders in the analyzed firms, they could feel exploited by family managers who are major shareholders and might hold divergent interests 
(MILLER and LE-BRETON-MILLER, 2006). Finally, quite often, private equity firms, who are financial investors themselves, have chosen most professional managers. As a result, one might expect that the chosen managers and the interviewed investors would hold similar interests. Nevertheless, the study's interviewees differ from private equity bankers and other short-term oriented investors. Value investors, by contrast, are concerned with the companies' long-term prospects.

All investors stated that they carried out the analysis of companies and management on a case-by-case basis. Moreover, management evaluation emphasized the abilities, personality and qualifications of the individual in charge rather than the management type - family or professional. This long-term perspective goes in line with Selznick's (1957) notion of institutional leader, which comprises leadership, character and critical experience. These three features of institutional leadership has inspired the analysis of interviewees' views regarding the most desirable characteristics in a retail top manager. Three characteristics - orientation for results, long-term vision, and CEO-owner - refer to Selznick's leadership. Two other features - good character and intentions, and consistency - pertain to Selznick's character.

Finally, two other aspects - expertise in retail and CEO's track record - have to do with Selznick's critical experience.

Regarding orientation for results, because fashion retail can be fascinating and glamorous, some managers might be carried away and focus on products and fashion shows to the detriment of results. Even though product focus is essential, an orientation for result has to be in place. Some firm founders and family members tend to be more passionate about their products and companies, as well as less cost conscious than professional managers. These tend to be more rational and objective, but according to respondents, this is not a rule. Moreover, some professional managers tend to exaggerate cost-cutting programs, which may jeopardize company's products and essence.

With respect to long-term vision, even though investors may not have a long-term perspective at all times, they all want the company to have an enduring vision to avoid diluting its assets. Family members tend to have longer-term vision than executives, who may change jobs quite often (FLECK, 2003; MILLER and LE BRETON-MILLER, 2006).

The CEO-owner notion relates to embracing an owner's perspective if not by fact (actually owning shares), but by behavior (acting as if he was). All investors view the CEO of Renner, José Galló, as a benchmark of professional management that embodies an owner perspective. One of them went even further, stating that companies that go bankrupt for taking too much risk usually are the ones that fail to have an owner. Family businesses, this investor believes, "may also fail, of course, but for different reasons; but not for taking too much risk". Owners are more careful regarding their own money, reputation and family name (MILLER and LE BRETON-MILLER, 2006).

Concerning good character and intentions, even though this might seem an obvious desired trait in business affairs, some shortterm oriented investors will not give weight to this quality, as long as management yields above-average returns. However, as pointed out by Hagstrom (2005), this feature is crucial for value investors, as can be seen by one of the respondents: "you need honest people both in management and on the board; you cannot trust that the audit companies will do their jobs". As regards consistency, respondents agreed that CEO's consistency in decisions and behaviors is crucial for investors to feel comfortable with an investment decision, because they know what to expect.

On the subject of expertise in retail, if managerial practices favor professional managers, this expertise in retail favors family managers, as they have grown inside the retail companies. The Brazilian context is quite challenging with respect to specific expertise. For one, retail family businesses are usually run by family members and do little investment on developing middle management. In addition, there is not yet a specialized workforce available for hiring. As a result, more often than not professional managers lack expertise in retail. Adapting to this sector is challenging, especially for those individuals whose background experience has been in the financial sector, since the financial and retail sectors require completely different skill sets.

As to the CEO's track record, in addition to having a positive track record, it is desirable to have some negative track record as well (some "scars", as one of the investor put it) from which the CEO has supposedly learned from. An exclusively positive track record could be due to mere luck and/or might infuse the CEO with an undesirable over-confidence that could result in a dangerous propensity to take riks. From this perspective, family managers would have an advantage, as they usually have longer tenures than professional CEOs, increasing therefore the chances of learning from their mistakes (MILLER and LE BRETON-MILLER, 2006). 


\section{Cultural credentials}

Another unexpected finding was the importance given to culture by respondents, specially coming from financial investors. They unanimously agreed on the relevance of culture in managing retail businesses. This is in consonance with Muzzio's (2013) and Hall and Nodqvist's (2008) ideas regarding the need of both formal and cultural competence to manage a business. Selznick's (1957) leadership role of a CEO also includes the concept of "institutional self-preservation", or "the maintenance of basic identity, with the integrity of a personal or institutional 'self'" (p. 142).

Hence, in addition to the above coded characteristics of an ideal CEO, investors mentioned the need of having what they called a "culture guardian", someone who would protect the company's culture and essence. In the growing and professionalizing route (even in family firms), processes and strategies tend to change over time. Thus, companies need someone to remind everyone of who they are, of the "dos and don'ts", of what is their essence and of what is off limits. In a family company, this role is usually performed by the founder (as CEO or on the board), or a descendent. According to the interviewees, this was the case in companies with a long history of success, such as Wal-Mart. In professionally managed firms, this is usually more challenging, but some have successfully done it. A case in point is Renner, which has had in its long time professional CEO a strong guardian. However, someone other than the CEO can also perform this role.

\section{Focus on short-term financial performance}

Counter-intuitively, these investors are not fond of CEOs with a strong focus on short-term financial performance and stockmarket prices. They prefer those with endurance, who can cope with short-term bumps for a longer-term vision and strategy. They believe many executives (professional managers in special) may have too much of a short-term horizon due to their financial compensation, thus focusing actions, and sometimes even accounting, to benefit short-term results only, in detriment to long-term performance. "I don't blame them, I just don't want them on my team", said one of the respondents frankly. In addition, in the words of another interviewee, some managers "get addicted to monitoring stock market prices and quarterly results". By aiming to please the financial markets, frequent and unnecessary changes in strategy may result.

Again, this is in line with Selznick's (1957) definition of a responsible leader, who should avoid opportunism, i.e. "the pursuit of immediate, short-run advantages in a way inadequately controlled by considerations of principle and ultimate consequence", p. 143; or "a narrow self-centeredness, in an effort to exploit other groups for immediate, short-run advantages", p. 146.

These attitudes may affect both professional and family managers. However, they possibly affect the former in greater magnitude than family managers, who usually have emotional and financial attachment to the business (MILLER and LE BRETON-MILLER, 2006), caring for its long-term reputation, profitability and survival to future generations.

\section{Corporate governance}

In consonance with the theoretical background, corporate governance issues are a substantial concern for these investors. Fundamentally, respondents think the CEO's interests have to be in line with minority shareholders' for the investment to be interesting, in accordance with empirical findings (MILLER and LE BRETON-MILLER, 2006) and (GAMA and RODRIGUES, 2003) as well as with the value investment principles (HAGSTROM, 2005). Usually, respondents believe, such alignment is greater when the CEO is a shareholder himself. He can either be a family member or a professional manager with stocks or stock options (investors differ in preferences), as long as interests are aligned and CEO is of good character, otherwise a principalprincipal agency problem might arise - in line with Gama and Rodrigues (2003).

Another interesting point mentioned by respondents was that not only FIM matters but also FIO. This issue has been raised by some authors (MILLER and LE BRETON-MILLER, 2006; SCIASCIA and MAZZOLA, 2008), who maintain the fundamental role that ownership structure plays in making an investment attractive. Sometimes too much of a dispersed control can be seen as detrimental by the investors herein interviewed, as they tend to like companies with "owners" (again, as long as interests are aligned), someone watching out for their money. 


\section{Family issues}

Despite the potential governance benefits of a family managed firm, investors agree that some negative family-related issues raised by scholars can be detrimental to a business.

A case in point is having too many family members in the top management team. As the firm grows, so do business complexity and family. However, it is highly unlikely that all, or a large number of family members, will be capable and prepared to occupy top positions in the organization. Thus, the presence of too many of them may indicate some degree of nepotism and lack of professionalism (DYER, 1989; MILLER and LE BRETON-MILLER, 2006; SCIASCIA and MAZZOLA, 2008). In addition, the complexity of relations and conflicts likely increase as family issues get mixed with organizational issues.

Another example is having a weak middle management, which, according to these investors, might indicate a problem for future succession; excessive dependence on top management on daily decisions; and company inability to attract and retain good talents - possibly due to lack of career perspectives, which is in line with Charan and Hofer (1984).

Finally, respondents have asserted that when two family generations fight for power, the company may undergo stagnation or lack a clear strategic direction until the fight is over - usually when the older person retires or dies. "And for very controlling people, just moving to the board isn't enough. They still keep trying to control the company from there", said one interviewee.

\section{Summing it up}

As already mentioned, according to respondents, the type of management (family or professional) is not a determining factor in selecting a company to invest. Management structure and style, on the other hand, seem to be more important. They also take into consideration how other financial players perceive and evaluate the company in question, especially mainstream quantitative short-term analysts, in order to understand how stocks are priced. The financial markets, they say, tend to be cyclical and have a short-term memory. As a result, mainstream analysts perform better evaluations of cases that resemble recent successes. For them, having an independent view of the companies and understanding the mainstream thinking is thus crucial for guessing the likely path of the stock prices. This reasoning is in line with the literature on value investing (HAGSTROM, 2005; GRAHAM, 1949; GRAHAM and DODD, 1951).

Nevertheless, their own valuation of the company relative to the stock price is still the most critical factor for placing a buy or sell order. If the company seems great, its management is a benchmark, and growth prospects are impressive, but the stock price already includes all these qualities, then there is no "margin of safety" to profit from (GRAHAM, 1949; HAGSTROM, 2005). Therefore, they just keep an eye on stock-prices, hoping it will drop below valuation level for them to buy it.

\section{CONCLUSIONS, LIMITATIONS AND RECOMMENDATIONS FOR FUTURE RESEARCH}

Both family and professional management have interesting advantages and shortcomings. Therefore, understanding each management type's traps is the first step to become a true "institutional leader", confusing leadership, character and critical experience (SELZNIK, 1957).

Our contribution for research has to do with suggesting that the discussion around professional versus family management alone may not help illuminate the subject matter. Moreover, the study suggests that the old institutionalism (SELZNIK, 1957) may be a source of fruitful concepts for future research.

Regarding practitioners, the study offers a few guidelines that may help neutralize the shortcomings each type of management has. Data analysis suggests that the more a leader's behavior fits Selznick's notion of institutional leadership, the higher the chances will be that $s /$ he may succeed from a long-term perspective.

If family managed, professionalize it - If family management is in place, the company should exploit all the benefits this kind of management provides but within a more professional environment.

1. Managers should be results-oriented, rational and objective in their decisions, relying more on formal and concrete data and not only on intuition, involving more individuals in the decision-making process. 
2. Family members working in the company should be limited to positions in accordance to their capabilities and qualifications. The family should develop a strong middle management, devoting attention to attracting and retaining talents.

3. Family issues and fights should be handled outside company borders.

4. Strict and clear rules should be established in order to avoid misunderstandings and generational disputes. These include establishing retirement age and prerequisites for family members to work in the company, among others.

5. Family members in top positions should manage the firm professionally. They should refrain from power abuse, as well as from extracting any financial value from the company for personal purposes. Instead, they should act on behalf of all shareholders.

If professionally managed, humanize it - Despite having strong formal qualifications, a CEO must also develop some soft ones to manage a business better, especially in retail, as this study indicates.

1. If a CEO does not have a strong expertise in retail (or in any specificities-rich sector), $s /$ he should be surrounded by and listen to those who do, especially employees who have longer working experience in the company and/or in the market.

2. The professional CEO should respect whoever plays the role of "culture guardian" of the company - a member of the board, a marketing director, the head stylist in the case of a fashion company, etc. It is very important to appreciate the company's culture and its "D.N.A." to really benefit from its capabilities.

3. The CEO must think of the company as a unique case, analyzing it very carefully and deeply understanding it, not trying to apply any pre-formatted package of managerial best practices learned in MBA classrooms or cloned from other successful enterprises.

4. The CEO must feel and act as if s/he owned the company, being more emotionally involved.

5. The board of directors has the important designation to control and give the right incentives to the CEO, guaranteeing that he will have the necessary drive and financial motivation to deliver short-term results but that he is also thinking long-term, aligned with all shareholders.

Finally, in both cases, CEOs must be clear and consistent in their thinking and behavior, have a long-term vision and think independently of the market. Too much and too constant attention to stock prices may also be a trap, as stock price oscillations will occur on the short-term, whereas the CEO must aim at the long-term value creation.

\section{Contributions, limitations and recommendations for future research}

The study contributions include addressing a relevant topic through an original perspective (value investors), offering guidelines to practitioners and suggesting that further research on family business might explore institutional leadership and old institutionalism notions. The study also suggests that despite being the main indicator of success by the scholars herein reviewed, accounting performance and profitability may not be the best financial instrument when analyzing family firms (or for comparing family and professional firms). These outcomes may not translate into value added for the average investor (minority shareholders), if adequate governing mechanisms are not in place (GAMA and RODRIGUES, 2013).

This study, however, is not without limitations, considering that it has investigated a small number of value investors located in Brazil. It would be interesting to replicate it in other geographical regions and to compare and contrast the results found. In addition, it would be interesting to contrast the view of these value investors with the view of other types of financial investors.

Finally, given the complexity of family businesses as well as of today's current corporate structure, it may not be sufficient to analyze management alone when contrasting family and non-family firms. This calls for a broader governance analysis, which includes not only management but also ownership structure and forms of corporate controls in place. 


\section{REFERENCES}

ABVTEX - Associação Brasileira do Varejo Têxtil - Relatório Anual 2016. Available at: <www.abvtex.org.br>. Accessed on: May 31, 2017.

ALLIO, M. K. Family Businesses: Their virtues, vices and strategic path. Strategy \& Leadership, v. 32, n. 4, p. 24-33, 2004.

AMBIMA - Associação Brasileira das Entidades dos Mercados Financeiros e de Capitais. Available at: <http://portal.anbima.com. br/Pages/home.aspx>. Accessed on: Sept. 2, 2015.

BENAVIDES-VELASCO, C. A.; QUINTANA-GARCIA, C.; GUZMÁN-PARRA, V. F. Trends in Family Business Research. Small Business Economics, v. 40 n. 1, p. 41-57, 2013.

BERENBEIM, R. How business families manage the transition from owner to professional management. Family Business Review, v. 3, n. 1, p. 69-110, 1990.

CASILLAS, J.; ACEDO, F. Evolution of the Intellectual Structure of Family Business Literature: a Bibliometric study of FBR. Family Business Review, v. XX, n. 2, p. 141-162, 2007.

CHANDLER, A. D. The Visible Hand: The managerial Revolution in American Business. Belknap Pres of Harvard University, Cambridge, MA, 1977. [Edition of 2002].

CHARAN, R.; HOFER, C. W. The transition to professional management: mission impossible? American Journal of Small Business, v. 9, n. 1, p. 1-11, 1984.

CHUA, J.; CHRISMAN, J.; SHARMA, P. Succession and Nonsuccession concerns of family firms and Agency Relationship with Nonfamily Managers. Family Business Review, v. XVI, n. 2, p. 89-106, 2003.

CYERT, R. M.; MARCH, J. G. A Behavioral Theory of the Firm. Englewoods Cliffs, New Jersey, Prentice-Hall, Inc., p. 26-43; 114-127, 1963.

DOLZ, C.; IBORRA, M; SAFÓN, V. Empresa Familiar, equipes administrativas, diversidade e ambidestria em grandes e pequenas empresas. Revista de Administração de Empresas, v. 55, n. 6 , p. 673-687, 2015.

DYER, W. G. Integrating professional management into a family owned business. Family Business Review, v. 2, n. 3, p. 221-235, 1989.

EISENHARDT, K. Building Theories From Case Study Research. Academy of Management Review, v. 14, n. 4, p. 532-550, 1989.

EISENHARDT, K.; GRAEBNER, M. Theory building from cases: opportunities and challenges. Academy of Management Journal, v. 50, n. 1, p. 25-32, 2007.

FLECK, D. Dois Motores do Crescimento Corporativo. Revista de Administração de Empresas, v. 43, n. 4, p. 10-24, 2003.

GALLO, M. A.; TÀPIES, J.; CAPPUYNS, K. Comparison of Family and Nonfamily Business: Financial Logic and Personal Preferences. Family Business Review, v. XVII, n. 4, p. 303-318, 2004.

GAMA, A. P. M; RODRIGUES, C. The Governance-Performance relations in publicly listed family controlled firms: an empirical analysis. Corporate Governance, Emerald Group., v. 13, n. 4 , p. 439-456, 2013.
GRAHAM, B. The Intelligent Investor: The Classic Text on Value Investing. Harper Collins Publishers, 1949.

GRAHAM, B.; DODD, D. Security Analysis. 3. ed. New York: McGrawHill, 1951.

GREINER, L. E. Evolution and Revolution as Organizations Grow. Harvard Business Review, v. 50, n. 4, p. 37-46, 1972.

HAGSTROM, R. The Warren Buffet Way. 2. ed. New Jersey: John Wiley \& Sons, Inc., 2005

HALL, A.; NORDQVIST, M. Professional Management in Family Businesses: Towards an extended understanding. Family Business Review, v. XXI, n. 1, p. 51-69, 2008.

HANDLER, W. C. Succession in family business: a review of the Research. Family Business Review, v. 7 n. 2, p. 133-157, 1994.

IDV - Instituto para Desenvolvimento do Varejo. Momentum 592 - A Década do Varejo. 20/11/2014. Available at: <http://www.idv. org.br/artigos/momentum-592-a-decada-do-varejo/>. Accessed on: Sept. 30, 2015.

JONES, A. M. The Elementary Structures of the Family Firm: an Anthropological Perspective. Human Organizations, v. 64, n. 3, p. 276-283, 2005.

MANN, P. H. Pessoas como fontes de dados. In: MANN, P. H. Métodos de investigação sociológica. 4. ed. Rio de Janeiro: Zahar Editores, 1979. Cap. 5. p.89-107

MILLER, D.; LE BRETON-MILLER, I. Family Governance and Firm Performance: Agency, Stewardship and Capabilities. Family Business Review, v. XIX, n. 1, p. 73-86, 2006.

MORRIS, M. H.; WILLIMS, R. W.; NEL, D. Factors Influencing Family Business Succession. International Journal of Entrepreneurial Behavior \& Research, v. 2 n. 3, p. 68-81, 1996.

MUZZIO, H. A consolidação da profissionalização da empresa familiar e o legado do fundador: concepções teóricas e implicações práticas. Teoria e Prática em Administração, v. 3, n. 2, p. 27-43, 2013.

PECANHA, A. R. O; OLIVEIRA, S. B. Empresa familiar, sim! Mas qual o problema, se a gestão é profissional? NAVUS - Revista de Gestão e Tecnologia, v. 5, n. 3, p. 126-135, 2015.

PWC - PRICEWATERHOUSECOOPERS. Varejo e Consumo 2014. Available at: https://www.pwc.com.br/pt/estudos/setores-atividade/ produtos-consumo-varejo.html>. Accessed on: Aug. 7, 2014.

QUEIROZ, V. S. The Good, the Bad and the ugly: estudo sobre pequenas e médias empresas familiares brasileiras a partir da teoria da ação de Pierre Bourdieu. Cad. EBAPE.BR, v. 6, n. 5, p. 1-17, 2008.

RODRIGUES, J.; ANDRE, M. A. M. Governance Bodies of Family Business. Revista de Empresa Familiar, v. 3, n. 1, p. 47-58, 2013.

SCIASCIA, S.; MAZZOLA, P. Family Involvement in Ownership and Management: Exploring nonlinear Effects on Performance. Family Business Review, v. 21, n. 4, p. 331-344, 2008. 
SELZNICK, P. Leadership in administration: a sociological interpretation. Harper \& Row Publishers, 1957.

TESTON, S. F.; FILIPPIM, E.S. Perspectivas e desafios da Preparação de sucessores para empresas familiares. RAC - Revista de Administração Contemporânea, v. 20, n. 5, p. 524-545, 2016.

TREVINYO-RODRIGUEZ, R. N. From a Family-Owned to a FamilyControlled Business: Applying Chandler's insights to explain family business transitional stages. Journal of Management History, v. 15, n. 3, p. 284-298, 2009.

VENTURA, R. Mudanças no perfil do consumo no Brasil: principais tendências nos próximos 20 anos. Macroplan- Prospectiva, Estratégia e Gestão, 2010.

WHETTEN, D. A. Organizational Growth and Decline Processes. Annual Review of Sociology, v. 13, p. 335-358, 1987.

Clarice Secches Kogut

M.Sc and D.Sc. candidate at COPPEAD Graduate School of Business / Universidade Federal do Rio de Janeiro (UFRJ), Rio de Janeiro - RJ, Brazil.

E-mail: clarice.kogut@coppead.ufrj.br

Denise Fleck

Ph.D. in Management; Associate Professor at COPPEAD Graduate School of Business/ Universidade Federal do Rio de Janeiro (UFRJ), Rio de Janeiro RJ, Brazil. E-mail: denise@coppead.ufrj.br 